\title{
Top management team diversity: positive in the short run, but negative in the long run?
}

\author{
Sabine Boerner, Marius Linkohr and Sabine Kiefer \\ University of Konstanz, Konstanz, Germany
}

\begin{abstract}
Purpose - This paper aims to investigate the moderating role of top management team (TMT) longevity on the TMT diversity-firm performance relationship.

Design/methodology/approach - The paper presents results from a quantitative longitudinal study of 59 TMTs in German companies in different industries.

Findings - For age diversity, dominant educational background diversity, and diversity in dominant industry experience, the curvilinear moderating effect of TMT longevity on the TMT diversity-firm performance relationship is confirmed. However, for organizational tenure diversity, the form of the moderating effect is contrary to expectations (being u-shaped).

Research limitations/implication - In line with previous studies, the results were sensitive to the performance measures in use. Furthermore, the results should not be generalized since they may be sensitive to the sector under study and the small sample size.

Originality/value - First, a curvilinear moderating effect of TMT longevity on the TMT diversity-firm performance relationship is investigated for the first time. Second, although the selected diversity dimensions have been investigated in previous TMT studies, they are examined simultaneously for the first time. Third, this study analyzes TMTs of large and medium-sized German corporations operating in a variety of sectors. Fourth, relating demographic data on TMTs collected in 2004 to performance data for the years 2004 to 2007, the present paper presents one of the few longitudinal studies in the context of TMT diversity.
\end{abstract}

Keywords Top management team, Longevity, Diversity, Moderator, Curvilinear, Longitudinal, Germany, Team working, Chief executives

Paper type Research paper

TMT diversity and firm performance: the ambivalent role of team longevity Theoretical reasoning allows for both positive and negative effects of TMT diversity on firm performance (Hambrick et al., 1996, p. 669). On the one hand, approaches relying on resource theory propose positive diversity effects (Bantel and Jackson, 1989; Webber and Donahue, 2001). On the other hand, according to social identity theory (Tajfel and Turner, 1986), self-categorization theory (Turner et al., 1987), and similarity attraction theory (Byrne, 1971), negative diversity effects can be expected. Empirical research has yielded inconsistent evidence about the effects of TMT diversity on organizational performance (for an overview see Certo et al. (2006)). While some studies report positive effects (e.g., Eisenhardt and Schoonhoven, 1990), others reveal negative (e.g., Murray, 1989; Simons et al., 1999) or even no effects (e.g., Michel and Hambrick, 1992; West and Schwenk, 1996). Accordingly, the meta-analysis by Certo et al. (2006) provides evidence for the existence of moderators of the TMT diversity-performance relationship. 
Several moderators of the TMT diversity-firm performance relationship have been identified in the literature. For example, Carpenter (2002) confirmed the firms' levels of internationalization to moderate the TMT diversity-firm performance relationship in large and medium-sized firms. Richard et al. (2004) found the firms' entrepreneurial orientation to be a moderator of the TMT diversity-performance relationship in banks' management groups. In addition, Hambrick $(1994,2007)$ suggested to focus on team processes when investigating the effects of TMT diversity. Like in any other team, those effects result from direct interaction of the team members. However, few TMT diversity studies have directly included team process moderators so far, such as team interdependence (Barrick et al., 2007), collaborative behavior, information exchange, and decentralized decision making (Boone and Hendriks, 2009). Instead, group longevity, that is, "the length of time group members have spent working together" (Pelled et al., 1999), has been investigated as a proxy for group processes in diverse TMTs. Since longevity may influence the nature of interaction processes in groups (Katz, 1982; Sethi et al., 2001), it has been analyzed as a moderator of the diversity-performance relationship in different types of work teams (Pelled et al., 1999; Qin, 2007; Schippers et al., 2003; Harrison et al., 1998). In TMTs, however, the moderating effect of longevity has been investigated only once. Drawing on potentially ambivalent effects of longevity on interaction processes, Carpenter (2002) compared the diversity-performance relationship in short-tenured versus long-tenured TMTs. Investigating 247 large and medium-sized companies, Carpenter found evidence for a stronger positive diversity-performance relationship in short-tenured compared to long-tenured TMTs.

The present paper intends to carry on the approach taken by Carpenter (2002). Similar to Carpenter, we interpret longevity as a proxy for interaction processes in TMTs. However, we expect a different moderating effect of longevity. While Carpenter contrasted two alternative hypotheses about the (reinforcing or buffering) moderating effects of longevity on the TMT diversity-performance relationship, the present paper provides an integration of these two lines of arguments. Analyzing the information processing processes in TMTs, we suggest a curvilinear (inverted-u-shaped) moderating effect of longevity on the TMT diversity-performance relationship. In short tenured teams, TMTs make use of their diversity while developing a shared task mental model (Rentsch and Klimoski, 2001), which in turn will enhance the elaboration of task relevant information. However, in long-tenured TMTs, the resources provided by diverse team members are either no longer present or no longer utilized in the TMT" $\mathrm{s}$ information processing. With rising longevity, the moderating effect of longevity on the diversity-performance relationship as described above should therefore decline.

In line with previous research (Hambrick and Mason, 1984; Cannella et al., 2008; Smith et al., 1994), we define TMT diversity as the extent to which the members of a TMT are heterogeneous with respect to demographics. Following the rationale of upper echelons theory (Hambrick et al. 1996; Hambrick, 2007), we investigate demographic variables as predictors of TMT members' cognitions and values. Demographic diversity is assumed to reflect TMT members' cognitive diversity (Finkelstein and Hambrick, 1996; Jackson et al., 1991), which in turn influences TMT decision-making processes and thus firm performance (Pegels et al., 2000a, b).

In particular, we consider TMT diversity concerning age, organizational tenure, dominant educational background, and dominant industry experience. All of these 
variables can be interpreted as proxies for team members' cognitive diversity, thus allowing a theoretical link to information processing in TMTs (Murray, 1989; Bantel and Jackson, 1989; Hambrick and Mason, 1984; Wiersema and Bantel, 1992). Our selection of diversity dimensions includes both readily detected attributes (i.e., age and tenure) and underlying attributes (i.e., dominant educational background and dominant industry experience) (Milliken and Martins, 1996). Moreover, relation oriented diversity (i.e., age) is considered as well as task related diversity (i.e., tenure, education, industry experience) (Jackson et al., 1995). In addition, empirical evidence for the effects on TMT performance is mixed for all of the selected diversity dimensions, namely, age (Bantel and Jackson, 1989, p. 110; Vroom and Pahl, 1971; Kilduff et al., 2000; Simons et al., 1999; Richard and Shelor, 2002), organizational tenure (Hambrick et al., 1996; Murray, 1989; Smith et al., 1994; Wiersema and Bantel, 1992; Bantel and Jackson, 1989), dominant educational background (Carpenter and Fredrickson, 2001; Wiersema and Bantel, 1992; Hambrick et al., 1996; Bantel and Jackson, 1989; Cannella et al., 2008), and dominant industry experience (Eisenhardt and Schoonhoven, 1990; Smith et al., 1994.) Hence, analyzing the moderating effect of longevity could be particularly promising for these dimensions of TMT diversity and their relationship to performance outcomes. According to the TMT literature, firm performance is defined as a company's financial performance as indicated in annual financial reports (Certo et al., 2006).

The paper makes several contributions to the existing literature on TMT diversity. First, a curvilinear moderating effect of longevity on the TMT diversity-firm performance relationship is investigated for the first time. Overall, this is the second study to analyze longevity as a moderator in diverse TMTs. Second, although the selected diversity dimensions have been investigated in previous separate TMT studies (see above), they are examined simultaneously for the first time. Third, this study analyzes TMTs of large and medium-sized German corporations operating in a variety of sectors. This supplements the existing research that is mainly carried out in the USA and focused on firms in only one or a few different sectors. Fourth, relating demographic data on TMTs collected in 2004 to performance data for the years 2004 to 2007, the present paper presents one of the few longitudinal studies in the context of TMT diversity.

\section{Theory and hypotheses}

Positive and negative effects of TMT diversity on firm performance

According to upper echelons theory (Hambrick and Mason, 1984), demographic heterogeneity is considered to be an important feature of TMTs. Since TMTs are involved in strategic leadership, they typically deal with complex, ambiguous, and ill-defined rather than routine problems (Hambrick, 1989). Therefore, information processing is one of the primary responsibilities of TMTs. Since TMTs take decisions which directly influence firm performance (Hambrick, 1989), the information processing abilities of TMTs are of particular importance to organizational functioning and performance. However, according to previous research, demographic heterogeneity can have either positive or negative effects on information processing in TMTs.

In order to allow for a theoretical link to information processing in TMTs (Murray, 1989; Bantel and Jackson, 1989; Hambrick and Mason, 1984; Wiersema and Bantel, 
1992), we focus on variables that can be interpreted as proxies for team members' cognitive diversity, namely, diversity in age, dominant educational background, and dominant industry experience. In addition, empirical evidence for the effects on TMT performance is mixed for all of these diversity dimensions, namely, age (Bantel and Jackson, 1989, p. 110; Vroom and Pahl, 1971; Kilduff et al., 2000; Simons et al., 1999; Richard and Shelor, 2002), dominant educational background (Carpenter and Fredrickson, 2001; Wiersema and Bantel, 1992; Hambrick et al., 1996; Bantel and Jackson, 1989; Cannella et al., 2008), and dominant industry experience (Eisenhardt and Schoonhoven, 1990; Smith et al., 1994.) Accordingly, analyzing the moderating effect of longevity could be particularly promising for these dimensions of TMT diversity and their relationship to performance outcomes.

According to resource theory, positive effects of TMT demographic diversity can be expected (Bantel and Jackson, 1989; Webber and Donahue, 2001; Certo et al., 2006). Diverse teams generally possess a broader range of perspectives, task-relevant knowledge, skills, and abilities, thereby providing a larger pool of resources for decision-making processes (Van Knippenberg et al., 2004, p. 1009). Moreover, due to the different professional networks they belong to, members of diverse TMTs are likely to have access to a broad range of information. By combining these resources, diverse teams are generally supposed to produce outcomes of higher quality than homogeneous teams (Bassett-Jones, 2005, p. 172). In TMTs, the diversity of perspectives and task-relevant knowledge is a valuable asset for the identification and interpretation of the various and complex environmental stimuli the team is confronted with. Each team member may attend to different cues and construct different understandings about a situation (Bantel and Jackson, 1989, p. 108). Hence, a diverse TMT gets a more complete picture of the firms' relevant environment.

Furthermore, when confronted with new information from people with different backgrounds, team members are forced to rethink their individual points of view and consider factors they may not have considered before. Hence, the decision-making process becomes more comprehensive (Simons et al., 1999, p. 664). Diversity within a TMT should therefore contribute to the processing of information within the team that is, to team members' exchange, discussion, and integration of ideas, knowledge, and insights that are relevant to the team's task. This in turn could reduce the tendency towards groupthink associated with homogeneous TMTs (Hambrick and Mason, 1984) and result in more elaborated team decisions.

However, according to similarity attraction theory (Byrne, 1971), social identity theory (Tajfel and Turner, 1986), and self-categorization theory (Turner et al., 1987), negative effects of TMT diversity on firm performance can be expected. TMT members' similarities and differences may be used as a basis for self categorization (Williams and O'Reilly, 1998, pp. 83-4). This is especially true for readily detected diversity dimensions, such as age and organizational tenure. Categorization processes may produce subgroups within the team and give rise to problematic inter-subgroup relations (Van Knippenberg et al., 2004, p. 1009), which may cause relationship conflicts (Jehn et al., 1999, p. 745; Pelled et al., 1999, p. 20). This effect has been investigated in several empirical studies of TMT diversity (e.g., Boone and Hendriks, 2009; Bantel and Jackson, 1989; Knight et al., 1999). Similarly, diverse teams include members representing different thought worlds (Dougherty, 1992), which bears the risk of rising value and goal-conflicts (Jehn et al., 1999; Gebert et al., 2006). 
This tendency is most likely for underlying diversity dimensions such as dominant educational background and dominant industry background.

According to Certo et al. (2006), demographic diversity and its potential for conflict may threaten both social integration and communication, which in turn will affect TMT team performance. Following O'Reilly et al. (1989, p. 22), social integration reflects "the attraction of the group, satisfaction with other members of the group, and social interaction among group members". Relationship and value conflicts will thus directly endanger the level of social integration in a TMT. Social integration has been linked to group pride, team spirit and teamwork (Seashore, 1977), and to greater efficiency in the coordination of tasks (e.g., O'Reilly et al., 1989). According to Smith et al. (1994), TMT social integration is positively related to firm performance. Value and relationship conflicts rising from demographic diversity will thus endanger social integration and thereby derogate effective decision making in TMTs.

Similarly, communication in TMTs is affected by value and relationship conflicts. Both types of conflicts impede members' acceptance of divergent ideas (see Gebert et al., 2006). Hence, the variety of information within a diverse TMT will not entirely be integrated in the team's decision making process. Under high levels of value and relationship conflicts, TMTs will thus fail to effectively use the potential benefits of demographic diversity in their information processing. Since effective communication is an essential prerequisite to transform diverse TMTs into "high-quality decision making units" (Boone and Hendriks, 2009, p. 167), conflicts will directly threaten TMT performance.

To sum it up, the benefits assumed in resource theory are likely to appear in TMTs only if demographic diversity is effectively expressed and integrated into the processing of information (Hambrick, 1994, 2007; Barrick et al., 2007; Boone and Hendriks, 2009). Otherwise, the negative effects of diversity, namely, social categorization and different thought worlds, are likely to occur which impede the elaboration of task-relevant information. Thus, the positive effects of TMT diversity on firm performance will only dominate if its negative effects are kept under control.

The effects of longevity on interaction in TMTs

Group longevity, that is, "the length of time group members have spent working together" (Pelled et al., 1999), has been investigated as a proxy for group processes in diverse TMTs. According to Carpenter (2002, p. 278), young TMTs could fail to fully realize the benefits of their diversity, while longer tenured TMTs had time to develop routines and shared understandings that allow them to utilize their distinctive backgrounds. In this paper, TMT longevity is interpreted as a proxy for interaction processes in the team that affects the degree to which the potentially beneficial effects of diversity are realized.

In general, TMTs are likely to be unproductive until members develop roles and patterns of interaction that enhance integration and good communication (Hambrick, 1995, p. 118; Smith et al., 1994, p. 421). Once members have learned to work with each other, shared values and norms may develop which improve group processes (Keck, 1997, p. 146; Hambrick and D'Aveni, 1992; Michel and Hambrick, 1992). Since the development of joint interaction patterns requires some time, team longevity is an important issue with regard to team processes and team outcomes. In particular, team longevity is expected to enhance both cohesion or social integration and 
communication (Eisenhardt and Schoonhoven, 1990, p. 509; Michel and Hambrick, 1992, p. 17) in TMTs.

First, longer tenured diverse TMTs are likely to develop higher levels of social integration than short tenured diverse TMTs (Smith et al., 1994). Research on team diversity suggests that the salience of demographic characteristics is likely to dissipate over time because demographically dissimilar group members begin to re-categorize themselves as in-group members (Qin, 2007). Increased familiarity tends to result in intensified information sharing and improved conflict resolution (Qin, 2007). Hence, the extent to which members of a team identify with the team and perceive a stake in the success of the team (see Sethi et al., 2001, p. 75) is a critical prerequisite to the effective integration of diverse ideas and perspectives (Van der Vegt and Bunderson, 2005, p. 535). As a result, the potential of diverse TMTs is more likely to be realized in longer tenured teams. Second, tenure is likely to enhance communication in diverse TMTs. Joint tenure could give a TMT the time to develop routines and shared understandings that allow them to utilize their distinctive backgrounds (Carpenter, 2002, p. 278; Keck, 1997). For example, longer tenured teams may develop a common language as a key to integrate differing "thought worlds" (see Dougherty, 1992) in a productive way. This may help to overcome the different vocabularies that team members have because of their different socialization experiences. In addition, longer tenured TMTs have time to develop so-called team transactive memory systems (Wegner, 1995), allowing each member to know about each other's area of expertise and how to benefit from this meta-knowledge by social interaction (Boone and Hendriks, 2009). Longevity thus allows for collective processes of learning effective interaction patterns in diverse TMTs, thereby facilitating team communication.

The moderating effect of longevity in TMTs

By enabling both social integration and team communication, TMT longevity will moderate the relationship between TMT diversity and firm performance. However, we propose the moderating effect of longevity on the TMT diversity-performance relationship to be curvilinear. Beyond a certain level, team longevity bears the risk of negative effects on the elaboration of task-relevant information. First, teams pass through different stages, and teams that have spent a long time together become committed to their particular solution strategies and methodologies, as well as increasingly narrow in their range of cognitive perspectives Katz (1982). Hence, long joint tenure might result in dysfunctionally high levels of cohesion that favor groupthink (see Janis, 1982). Accordingly, Katz (1982) found an inverted u-shaped relationship between group tenure and both performance and communication in R\&D teams. Similarly, Pelled et al. (1999) found a negative relationship between diversity and desired task conflicts under high levels of group longevity in cross-functional work teams. Applying this reasoning to TMTs, Keck (1997) claimed that TMT members' thinking and behavioral patterns tend to converge over time. Second, if team members remain together for long periods, they begin to decrease communication with the outside and filter outside information that may be potentially disruptive, but beneficial to successful performance (Zenger and Lawrence, 1989). Following previous research (Carpenter, 2002; Keck, 1997: 146), this argumentation can equally be applied to diverse TMTs. Hence, the beneficial effects of TMT members' access to different professional networks is expected to be no longer used in long tenured teams. 
Since all of the diversity dimensions considered in this paper are expected to be linked to TMTs' information processing in a similar way, we hypothesize the following effects of TMT diversity in age, organizational tenure, dominant educational background, and dominant industry experience on firm performance.

Hypotheses. TMT longevity moderates the relationship between age diversity $(H 1)$, diversity in organizational tenure (H2), diversity in dominant educational background (H3), diversity in dominant industry experience $(H 4)$ and firm performance in a curvilinear way. The effect of diversity on firm performance will be positive in TMTs with short longevity; in TMTs with high longevity, this moderating effect will decline.

\section{Method}

Sample and data collection

In order to identify a sample of TMTs in German companies in different industries with nevertheless comparable data, we consulted the "DAX" index and the "MDAX" index. These indices include nearly all large and mid-sized German corporations whose stocks are being traded at the stock exchange in Frankfurt. For the purpose of this study, a formal definition of TMT was used (see Kiefer, 2005, p. 45). According to the German Stock Corporation Act (AktG) (see Wirth et al., 2004), a TMT is defined as the company's executive board (sec. $76 \S 1 \mathrm{AktG}$ ) which is elected by the supervisory board (sec. $84 \mathrm{AktG}$ ). Applying this definition, the resulting population consisted of 400 top managers in 80 TMTs.

The first step was to collect individual data for all members of the executive boards of each company. Basic information on their board of executives was collected via information on the companies' web pages. Further information was found in business reports and press releases of the companies. In addition, email requests were sent to those companies that did not provide full information on their executive board members. From this request, about half of the companies provided the required information, while the others refused for confidentiality reasons. If the information up to that point still was not sufficient, "Munziger Online Database" and "Lexis Nexis Database" were consulted as key sources for TMT demographic information. For single missing values within a team, general search engines such as Google were applied in addition.

Data on the composition of executive boards were collected from July 2004 until the end of September 2004. Data on firm performance were collected from September 2008 until the end of October 2008, referring to the years 2004 to 2007. Because of this longitudinal design, the original sample was reduced by those firms which were no longer publicly traded in 2008. In addition, cases with multiple outliers on several variables and companies with missing values on the independent or dependent variables were excluded, resulting in a final sample of 59 TMTs (including 74 per cent of all TMTs in the German DAX and MDAX) operating in nine different sectors (i.e., basic materials, cyclical consumer goods and services, financials, healthcare, industrials, non-cyclical consumer goods and services, technology, telecommunication services, utilities).

Dependent and independent variables

As Otley (2007, p. 16) points out, there is no definitive set of financial ratios that can be used to measure firm performance. Rather, different measures assess different aspects 
of financial performance. In a meta-analysis of 27 empirical studies on the relationship between TMT characteristics and firm financial performance, Certo et al. (2006, p. 820) identified return on assets (ROA) or average ROA over a three-year period, ROA growth, average return on equity (ROE) over a three year period, and sales growth as performance indicators. We therefore included these four performance measures in the present study. In order to address one of the blind spots in research as revealed in the above meta-analysis by Certo et al. (2006, p. 834), we additionally integrated ROE growth. The resulting five performance measures were calculated according to annual financial reports of the companies under study. For each measure, we provided a short time version (2004/2005) and a long-term version (2004/2007).

ROA is an appropriate performance measure since the efficient use of resources is important for firms in all sectors (Keck, 1997, p. 150). To reduce bias caused by single-year outliers (see Cannella et al., 2008, p. 773), ROA was calculated as net income divided by total assets for 2005 (short-term version) and averaged over three years (2005/2007; long-term version), respectively. ROE is also an important financial ratio indicating the percentage of profit from each euro shareholders invested and thus allows shareholders to compare different investment opportunities (Smith et al., 1994, p. 427). ROE was calculated as net income divided by total equity for 2005 (short-term version) and averaged over three years (2005/2007; long- term version), respectively.

While accounting measures such as RAO and ROE may be critical in samples of firms with varying sector membership (e.g., Carpenter, 2002), growth rates such as growth in profitability or sales should be less branch dependent than absolute measures, and can thus be used to compare different industry sectors (see Keck, 1997, p. 150). Furthermore, growth rates are likely to be more closely linked to recent behavior than overall profitability or sales, which are more heavily influenced by distant historical factors (Simons et al., 1999, p. 667). In this study, Three growth measures were used, i.e., ROE growth, ROA growth and sales growth. ROA growth was calculated as the difference between "net income divided by total assets" in 2005 (2007 for the long-term version) and 2004 divided by the net income/total assets ratio for 2004. ROE growth was calculated in analogy to ROA growth. Sales growth complements the above financial ratios by assessing a firm's ability to increase its revenues without paying attention to costs. Sales growth was calculated as the growth rate in total revenues from 2004 to 2005 (2007), dividing the difference between total revenues in 2005 (2007 for the long-term version) and 2004 by total revenues in 2004 .

Age of TMT members was calculated by subtracting their year of birth from 2004. TMT members' age diversity was calculated using the coefficient of variation, defined as the standard deviation divided by the mean (Bantel and Jackson, 1989). Being a scale invariant measure, this coefficient is preferable to the standard deviation or variance for interval scaled variables (Allison, 1978). The larger the coefficient of variation, the greater the diversity within the team.

Organizational tenure of a team member was measured as the number of years he or she had spent with the firm. For those cases that had recently undergone a merger or an acquisition, information was gathered on the date of entry into the original company. To determine TMT diversity in organizational tenure, the coefficient of variation for organizational tenure was calculated.

Diversity in dominant educational background was measured using the highest education level achieved by the team members. Similar to classifications commonly 
used in the literature (e.g., Carpenter and Fredrickson, 2001; Hambrick et al., 1996; Wiersema and Bantel, 1992, 1993), team members were categorized into eight educational specializations (i.e., arts, sciences, engineering, math, business, economics, law, and other). The Blau (1977) heterogeneity index was used to calculate diversity in educational background. This index is a frequently used diversity measure for categorical variables (e.g., Bantel and Jackson, 1989; Keck, 1997; Michel and Hambrick, 1992; Pegels et al., 2000a, p. 917) and can take values from 0 to 1, with high values indicating a more heterogeneous TMT.

Diversity in dominant industry experience was measured by identifying the kind of industry in which each TMT member had spent the main part of his career. Thirteen different industries have been distinguished (i.e., financials, pharmaceuticals and healthcare, media, consumer goods, utilities, logistics, industrials and automotive, engineering and construction, basic materials, consulting, technology, civil service, and other). The diversity score was calculated using the Blau (1977) heterogeneity index.

\section{Moderator variables}

TMT longevity was measured as the time since the last joining of a new TMT member, calculated in years. TMTs evolve over time through exit or retirement of old and the entrance of new members. Compared with other types of organizational groups, TMTs tend to be relatively small (Leblanc and Schwartz, 2007). In addition, TMT members typically are highly ambitious individuals with high levels of expertise who are likely to engage intensively in TMT team processes (Barrick et al., 2007). We therefore assume that the entrance of a new member might be quite disruptive, even though a TMT does not become a new team every time a new member joins. Keeping this in mind, we expected that our measurement of TMT longevity would be more sensitive to the influence which new member's entry has on the team processes considered in this paper than average joint tenure or median tenure of the TMT (Carpenter, 2002; Smith et al., 1994).

\section{Control variables}

Firm size can influence firm performance (Barrick et al., 2007; Carpenter et al., 2004; Cohen and Bailey, 1997; Michel and Hambrick, 1992) and was therefore included as a control variable. Two alternative indices were used to measure firm size. First, the natural logarithm of total assets (see Carpenter and Fredrickson, 2001; Richard et al., 2004: 260) and, second, the natural logarithm of the number of full-time employees or equivalents (see Simons et al., 1999) as reported in the company financial statements.

TMT size, measured by the number of TMT members, was included as a control variable for two reasons. First, it has a strong influence on the group's level of diversity (Blau, 1977; Boone and Hendriks, 2009), since larger TMTs have more potential for dissimilarity. (Wiersema and Bantel, 1992, p. 100). Second, team size can be directly linked to group process and the resulting performance outcomes. As Hambrick and D'Aveni (1992, p. 1449) state, "at a basic level, the resources available on a team result from how many people are on it". On the one hand, the cognitive resources of a larger group may contribute to improved group decision-making, creativity, and performance (Bantel and Jackson, 1989; Webber and Donahue, 2001). On the other hand, the larger group may suffer from problems of control, coordination, communication, and lack of 
social integration with the result of declined performance (Smith et al., 1994, pp. 416, 422).

Team members' average organizational tenure and average age are also standard control variables when tenure and age diversity are calculated. They were included in the study, using the coefficient of variation (Cannella et al., 2008; Carpenter and Fredrickson, 2001).

Data analysis

To test our hypotheses, moderated hierarchical regression analyses were used, as suggested by Aiken and West (1991), Jaccard and Turrisi (2003), and Cohen (2003). This variant of ordinary least squares (OLS) regression analysis is frequently used in diversity research to test moderating effects (e.g., Bunderson and Sutcliffe, 2002, p. 887; Lovelace et al., 2001, p. 786; Mohammed and Angell, 2004, p. 1027; Sethi et al., 2001, p. 80; Smith et al., 1994, p. 427; Van der Vegt and Bunderson, 2005, p. 539). Separate hierarchical regression models were calculated for the different measures of firm performance and the two periods of time (i.e., 2004/2005 and 2004/2007).

The moderated hierarchical regression analyses included the following four steps. In step 1, all control variables were entered, namely, firm size measured by total assets, firm size measured by the number of employees, TMT size, mean firm tenure of the TMT, and mean age of the TMT. In step 2, the main effects of TMT longevity and the diversity variables (i.e., age diversity, firm tenure diversity, diversity in dominant educational background, and diversity in dominant industry experience) on firm performance were entered. In step 3, the four linear-by-linear interaction terms between TMT longevity and each of the four diversity types were added to the model resulting from step 2. In step 4, the four quadratic-by-linear interaction terms between TMT longevity squared and each of the four diversity types were entered into the regression model (cp. Jaccard and Turrisi, 2003, p. 61). This last step tests the hypotheses that TMT longevity moderates the relationship between diversity and firm performance in a curvilinear way.

\section{Results}

Preliminary analyses

Descriptive statistics and bivariate correlations for all variables under study are presented in Tables I and II. The results show that the examined corporations varied heavily in size (measured by either total assets or number of employees), illustrating the need to control for these factors. The examined TMTs consisted of five members on average (ranging from two members to 12 members; $\mathrm{SD}=7$ ). Independent of the measurement, TMT size was significantly positively correlated with company size ( $r=0.39, p<0.01$ for total assets and $r=0.44, p<0.01$ for number of employees), indicating that larger corporations had larger TMTs. Only one diversity type was significantly correlated with TMT size, namely, diversity in dominant educational background $(r=0.55, p<0.01)$. On average, the members of the TMTs have been in their firms for about 12 years (ranging from one to almost 30 years; $\mathrm{SD}=7.14$ ). The examined TMT members were about 51 years old on average (ranging from 40 to 59 years; $\mathrm{SD}=4.13$ ). TMTs had an average longevity of about one year and four months (ranging from zero to four years; $\mathrm{SD}=11$ months), indicating that the TMTs under study frequently change in their composition. 


\begin{tabular}{|c|c|c|c|c|c|c|c|c|c|c|c|c|c|c|c|}
\hline & & Mean & SD & Min & Max & 1 & 2 & 3 & 4 & 5 & 6 & 7 & 8 & 9 & 10 \\
\hline $\begin{array}{r}1 \\
\\
2 \\
3 \\
4 \\
5 \\
6 \\
7 \\
8 \\
9 \\
10 \\
11 \\
12 \\
13 \\
14 \\
15 \\
16 \\
17 \\
18 \\
19 \\
20\end{array}$ & $\begin{array}{l}\text { Total assets (in mio. } \\
\text { euro) } \\
\text { Employees } \\
\text { Size TMT } \\
\text { Mean firm tenure } \\
\text { Mean age } \\
\text { TMT longevity } \\
\text { Age diversity } \\
\text { Firm tenure diversity } \\
\text { Dom. edu. diversity } \\
\text { Dom. ind. diversity } \\
\text { ROE growth (04-05) } \\
\text { ROE growth (04-07) } \\
\text { ROE (05) } \\
\text { ROE (05-07) } \\
\text { ROA growth (04-05) } \\
\text { ROA growth (04-07) } \\
\text { ROA (05) } \\
\text { ROA (05-07) } \\
\text { Sales growth (04-05) } \\
\text { Sales growth (04-07) }\end{array}$ & $\begin{array}{r}77,582.46 \\
66,971.63 \\
5.22 \\
12.66 \\
51.51 \\
1.37 \\
0.12 \\
0.65 \\
0.55 \\
0.25 \\
0.29 \\
0.23 \\
0.15 \\
0.16 \\
0.36 \\
0.26 \\
0.05 \\
0.05 \\
0.04 \\
0.12\end{array}$ & $\begin{array}{r}189,444.40 \\
106,215.00 \\
2.13 \\
7.06 \\
4.28 \\
0.88 \\
0.05 \\
0.33 \\
0.18 \\
0.25 \\
0.58 \\
0.42 \\
0.08 \\
0.08 \\
0.70 \\
0.49 \\
0.05 \\
0.05 \\
0.17 \\
0.11\end{array}$ & $\begin{array}{r}417.00 \\
3.00 \\
2.00 \\
1.00 \\
40.00 \\
0.00 \\
0.00 \\
0.00 \\
0.00 \\
0.00 \\
-0.83 \\
-0.85 \\
0.02 \\
0.04 \\
-0.84 \\
-0.98 \\
0.00 \\
0.00 \\
-0.69 \\
-0.10\end{array}$ & $\begin{array}{r}1,058,610.00 \\
430,000.00 \\
12.00 \\
29.50 \\
59.43 \\
4.00 \\
0.19 \\
1.44 \\
0.81 \\
0.78 \\
2.22 \\
2.59 \\
0.44 \\
0.38 \\
2.66 \\
2.93 \\
0.25 \\
0.27 \\
0.49 \\
0.55\end{array}$ & $\begin{array}{l}0.24^{*} \\
0.38^{* * *} \\
0.15 \\
0.16 \\
0.02 \\
-0.07 \\
0.05 \\
-0.02 \\
0.03 \\
0.15 \\
0.06 \\
-0.15 \\
-0.13 \\
0.20 \\
0.07 \\
-0.32^{* *} \\
-0.33^{* *} \\
0.20 \\
0.08\end{array}$ & $\begin{array}{l}0.54^{* * *} \\
0.20 \\
0.31^{* *} \\
-0.14 \\
-0.06 \\
0.02 \\
0.15 \\
0.03 \\
0.15 \\
0.01 \\
-0.14 \\
-0.17 \\
0.11 \\
0.05 \\
-0.24^{*} \\
-0.22 \\
-0.13 \\
-0.27^{* *}\end{array}$ & $\begin{array}{c}0.36^{* * *} \\
0.34^{* *} \\
-0.39^{* * *} \\
0.09 \\
-0.06 \\
0.50^{* * *} \\
-0.14 \\
0.04 \\
0.04 \\
-0.05 \\
-0.11 \\
0.07 \\
0.11 \\
-0.11 \\
-0.14 \\
-0.05 \\
-0.23^{*}\end{array}$ & $\begin{array}{c} \\
0.53^{* * *} \\
-0.12 \\
0.04 \\
-0.21 \\
0.27^{*} \\
-0.39^{* * *} \\
0.04 \\
0.07 \\
-0.02 \\
0.11 \\
0.04 \\
0.14 \\
-0.01 \\
0.10 \\
0.01 \\
-0.13\end{array}$ & $\begin{array}{c}0.00 \\
-0.22 \\
0.06 \\
0.46^{* * *} \\
-0.09 \\
-0.04 \\
0.07 \\
-0.08 \\
0.02 \\
-0.05 \\
0.19 \\
-0.13 \\
0.06 \\
-0.02 \\
-0.26^{*}\end{array}$ & $\begin{array}{r}-0.25^{*} \\
-0.03 \\
-0.23^{*} \\
0.09 \\
-0.14 \\
0.02 \\
-0.04 \\
0.05 \\
-0.15 \\
0.00 \\
-0.02 \\
0.07 \\
0.11 \\
0.05\end{array}$ & $\begin{array}{r}0.12 \\
0.21 \\
0.11 \\
-0.07 \\
0.02 \\
-0.06 \\
0.07 \\
-0.12 \\
0.00 \\
-0.06 \\
0.19 \\
0.06\end{array}$ & $\begin{array}{c}0.27^{*} \\
0.28^{* *} \\
-0.02 \\
0.02 \\
0.14 \\
0.15 \\
0.03 \\
0.09 \\
0.23^{*} \\
0.21 \\
-0.16 \\
-0.11\end{array}$ & $\begin{array}{c}-0.06 \\
-0.11 \\
0.03 \\
0.28^{* *} \\
0.26^{*} \\
-0.04 \\
0.15 \\
0.31^{* *} \\
0.30^{* *} \\
-0.05 \\
-0.27^{* * *}\end{array}$ & $\begin{array}{r}0.02 \\
-0.17 \\
-0.07 \\
-0.09 \\
-0.02 \\
-0.17 \\
-0.13 \\
-0.06 \\
0.00 \\
-0.06\end{array}$ \\
\hline & otes: $n=54,{ }^{*} p<0.1$ & ${ }^{* *} p<0.0$ & $5,{ }^{* * *} p<$ & & & & & & & & & & & & \\
\hline
\end{tabular}




\begin{tabular}{|c|c|c|c|c|c|c|c|c|c|c|}
\hline & & 11 & 12 & 13 & 14 & 15 & 16 & 17 & 18 & 19 \\
\hline 1 & Total assets (in mio. euro) & & & & & & & & & \\
\hline 2 & Employees & & & & & & & & & \\
\hline 3 & Size TMT & & & & & & & & & \\
\hline 4 & Mean firm tenure & & & & & & & & & \\
\hline 5 & Mean age & & & & & & & & & \\
\hline 6 & TMT longevity & & & & & & & & & \\
\hline 7 & Age diversity & & & & & & & & & \\
\hline 8 & Firm tenure diversity & & & & & & & & & \\
\hline 9 & Dom. edu. diversity & & & & & & & & & \\
\hline 10 & Dom. ind. diversity & & & & & & & & & \\
\hline 11 & ROE growth (04-05) & 0.11 & & & & & & & & \\
\hline 12 & ROE growth (04-07) & 0.20 & $-0.27^{* *}$ & & & & & & & \\
\hline 13 & ROE (05) & 0.01 & 0.02 & $0.82 * * *$ & & & & & & \\
\hline 14 & ROE (05-07) & $0.94 * * *$ & 0.07 & $0.36 * *$ & 0.07 & & & & & \\
\hline 15 & ROA growth (04-05) & 0.12 & $0.94^{* * *}$ & -0.12 & 0.13 & 0.14 & & & & \\
\hline 16 & ROA growth (04-07) & 0.17 & -0.17 & $0.81^{* * *}$ & $0.60 * * *$ & $0.33 * *$ & -0.02 & & & \\
\hline 17 & ROA (05) & -0.03 & -0.10 & $0.65^{* * *}$ & $0.70^{* * *}$ & 0.06 & 0.09 & $0.83 * * *$ & & \\
\hline 18 & ROA (05-07) & 0.14 & -0.02 & -0.02 & -0.11 & 0.13 & -0.17 & -0.08 & $-0.33^{* *}$ & \\
\hline 19 & Sales growth (04-05) & 0.19 & -0.03 & -0.10 & -0.11 & 0.13 & $-0.23^{*}$ & -0.10 & -0.17 & $0.54^{* * *}$ \\
\hline \multicolumn{11}{|c|}{ Notes: $n=54,{ }^{*} p<0.1,{ }^{* *} p<0.05,{ }^{* * *} p<0.01$} \\
\hline
\end{tabular}


Nearly all of the alternative indices measuring firm performance were highly intercorrelated. This is true for the two growth measures ROE growth and ROA growth $(r=0.94 ; p<0.01$, for both the short- and long-term versions) and the two absolute financial indicators ROE and ROA $(r=0.81 ; p<0.01$ for the short-term version and $r=0.70 ; p<0.01$ for the long-term version). As a result, separate analyses were warranted only for one of the absolute financial indicators and for two of the growth measures. We therefore decided to consider only three performance indicators in the further analyses, namely, ROE, ROE growth, and sales growth. To test for multicollinearity, the variance inflation factors (VIF) of the independent variables were examined conducting OLS regressions. To minimize multicollinearity, all independent variables were mean centered by replacing values with deviations from the means (Hamilton, 2006, p. 212; Jaccard and Turrisi, 2003, p. 28). After mean centering all independent variables, the largest VIF was less than 10. Thus, multicollinearity was not a problem (Chatterjee et al., 2000, p. 291).

\section{Testing the hypotheses}

Regression analyses. The results of hypotheses testing are presented in Table III (2004-2005) and Table IV (2004-2007). Separate models were calculated for the alternative measures of firm performance.

Step 1 is a baseline model, testing the control variables. Only firm size (measured by the natural logarithm of total assets) turned out to be significant, indicating a weak negative effect $(\beta=-0.229 ; p<0.1$; see Table IV) on firm performance, albeit only if measured by ROE in 2005/2007 (see Model 2). Step 2 added the main effects of the independent and moderating variables. Team longevity showed a significantly positive effect on firm performance if measured by ROE growth in 2004/2005 (see Model $1 ; \beta=0.410, p<0.05$; Table III). The same is valid for age diversity (see Model $1 ; \beta=0.261, p<0.1$; Table III). Firm tenure diversity had a significantly positive effect on ROE in 2005 (see Model $2 ; \beta=0.319, p<0.05$; Table III) and on sales growth in 2004/2007 (see Model 3; $\beta=0.588, p<0.01$; Table IV). Dominant educational diversity had a significant direct positive impact on firm performance, albeit only if measured by ROE in 2005/2007 (see Model 2; $\beta=0.508, p<0.01$; Table IV).

In Step 3, the linear-by-linear interactions were added, revealing significant results for ROE as performance measure. For short-term ROE (2005), three of the linear-by linear interactions were significant (see Model 2, Table III), namely, the interaction between firm tenure diversity and TMT longevity $(\beta=0.844, p<0.01)$, the interaction between dominant educational diversity and TMT longevity $(\beta=-0.0247, p<0.05)$, and the interaction between dominant industry diversity and TMT longevity $(\beta=-0.0415, p<0.05)$. For long-term ROE (2005/2007), the interaction between age diversity and TMT longevity $(\beta=-0.0681, p<0.01)$ and the interaction between dominant industry diversity and TMT longevity $(\beta=0.0631$, $p<0.1$ ) were significant (see Model 2, Table IV).

Step 4 further added the quadratic-by-linear interactions to test the hypotheses. For each of the diversity types under study, a significant quadratic-by-linear interaction was found. However, the results were sensitive to the performance measures. For short-term ROE growth (see Model 1; Table III), three of the four tested quadratic-by-linear interactions were significant, namely, the interaction between TMT longevity (squared) and age diversity $(\beta=-0.552, p<0.05)$, the interaction 


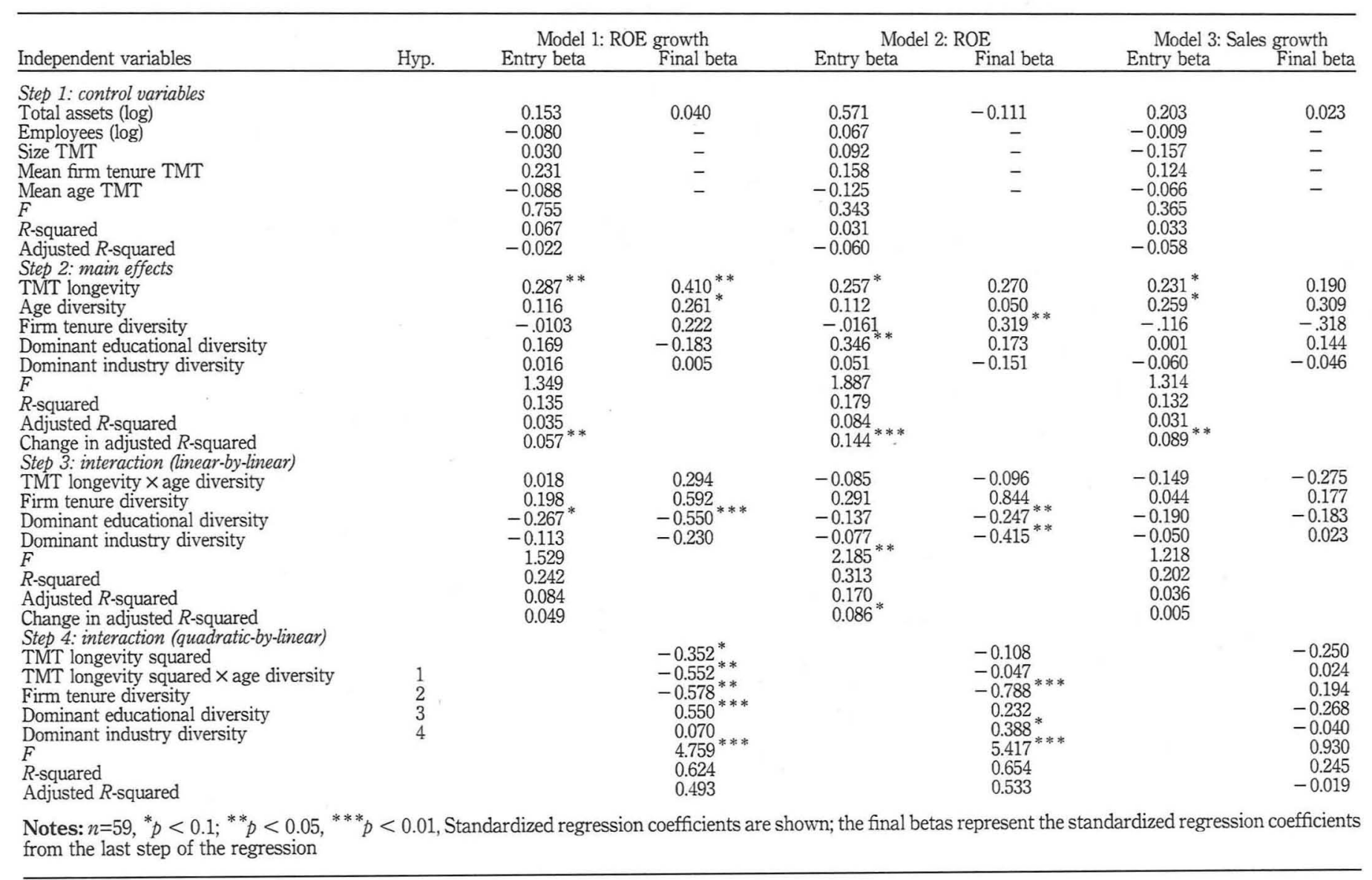




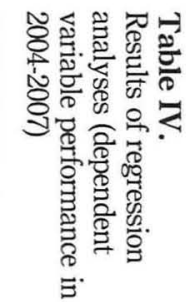

Nov

\begin{tabular}{|c|c|c|c|c|c|c|c|}
\hline \multirow{5}{*}{ 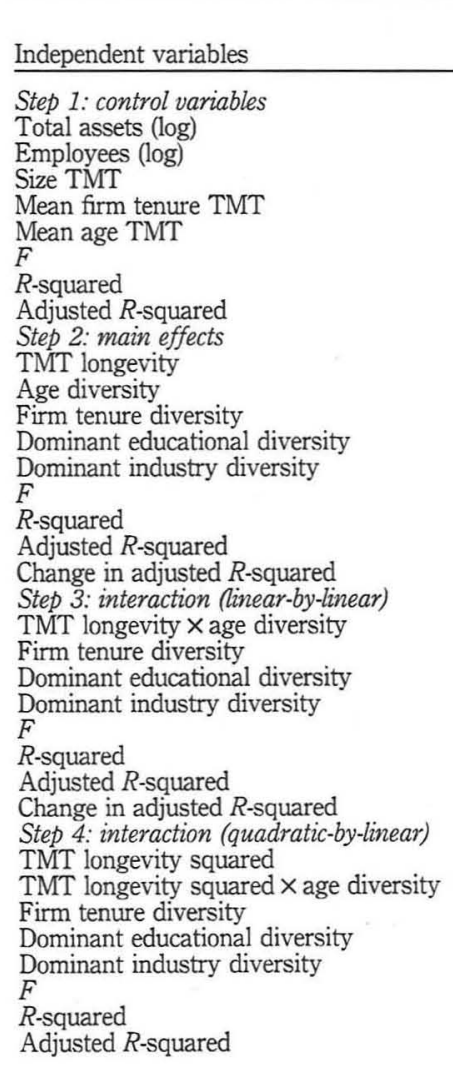 } & Hyp. & \multicolumn{2}{|c|}{$\begin{array}{l}\text { Model 1: ROE growth } \\
\text { Entry beta } \\
\text { Final beta }\end{array}$} & \multicolumn{2}{|c|}{$\begin{array}{l}\text { Model 2: } \\
\text { Entry beta } \\
\text { Final beta }\end{array}$} & \multicolumn{2}{|c|}{$\begin{array}{l}\text { Model 3: Sales growth } \\
\text { Entry beta } \\
\text { Final beta }\end{array}$} \\
\hline & & $\begin{array}{r}0.191 \\
-0.320 \\
0.009 \\
0.058 \\
0.175 \\
0.563 \\
0.055 \\
-0.043\end{array}$ & & $\begin{array}{c}-0.346^{*} \\
0.079 \\
0.005 \\
0.162 \\
-0.017 \\
1.122 \\
0.105 \\
0.011\end{array}$ & $\begin{array}{c}-0.222^{*} \\
- \\
- \\
-\end{array}$ & $\begin{array}{r}0.162 \\
-0.097 \\
-0.226 \\
0.058 \\
-0.204 \\
1.145 \\
0.107 \\
0.013\end{array}$ & $\begin{array}{c}-0.112 \\
- \\
= \\
-\end{array}$ \\
\hline & & $\begin{array}{r}0.071 \\
0.007 \\
0.111 \\
-0.006 \\
-0.217 \\
0.423 \\
0.051 \\
-0.010 \\
-0.027\end{array}$ & $\begin{array}{r}-0.039 \\
0.046 \\
0.357 \\
0.055 \\
-0.382\end{array}$ & $\begin{array}{c}0.059 \\
-0.082 \\
0.034 \\
0.283^{*} \\
-0.057 \\
1.518 \\
0.162 \\
0.055 \\
0.044^{*}\end{array}$ & $\begin{array}{l}-0.525 \\
-0.305 \\
0.162 \\
0.508 * * \\
0.102\end{array}$ & $\begin{array}{c}0.015 \\
0.115 \\
-0.018 \\
-0.284^{*} \\
-0.099 \\
0.854 \\
0.098 \\
-0.017 \\
-0.030\end{array}$ & $\begin{array}{l}0.024 \\
-0.588 * \\
-0.060 \\
-0.399\end{array}$ \\
\hline & & $\begin{array}{r}0.095 \\
0.125 \\
-0.024 \\
0.015 \\
0.280 \\
0.061 \\
-0.157 \\
-0.087\end{array}$ & $\begin{array}{r}0.088 \\
0.399 \\
-0.110 \\
-0.288\end{array}$ & $\begin{array}{c}-0.132 \\
0.210 \\
0.238 \\
0.271^{* *} \\
2.25{ }^{* *} \\
0.344 \\
0.191 \\
0.136^{* *}\end{array}$ & $\begin{array}{c}-0.681 * * * \\
0.223 \\
0.212 * \\
0.631^{*}\end{array}$ & $\begin{array}{r}-0.078 \\
-0.166 \\
-0.048 \\
-0.098 \\
0.697 \\
-0.140 \\
-0.061 \\
-0.044\end{array}$ & $\begin{array}{c}-0.054 \\
-0.0658 \\
0.541^{*} \\
-0.452\end{array}$ \\
\hline & $\begin{array}{l}1 \\
2 \\
3 \\
4\end{array}$ & & $\begin{array}{r}0.071 \\
-0.147 \\
-0.458 \\
-0.131 \\
0.336 \\
0.281 \\
0.256 \\
0.100\end{array}$ & & $\begin{array}{c}-0.551 \\
0.722^{* *} \\
-0.103 \\
-0.391 \\
-0.602 \\
2.493^{* *} \\
0.496 \\
0.297\end{array}$ & & $\begin{array}{c}0.810^{*} \\
0.524 \\
0.061 * \\
-0.341 \\
0.737 \\
1.010 \\
0.285 \\
0.003\end{array}$ \\
\hline Notes: $n=55,{ }^{*} p<0.1,{ }^{* *} p<0.05,{ }^{* *}$ & & & & & & & \\
\hline
\end{tabular}


between TMT longevity (squared) and firm tenure diversity $(\beta=-0.578, p<0.05)$, and the interaction between TMT longevity (squared) and educational diversity $(\beta=0.550, p<0.01)$. All in all, Model 1 was capable of explaining a significantly large part of the variance in short-term $\mathrm{ROE}$ growth $\left(R^{2}=0.49, p<0.01\right)$. For long-term ROE growth, however, no significant interaction effect was found (see Model 1; Table IV). For short-term ROE (see Model 2; Table III), only the interaction between TMT longevity (squared) and firm tenure diversity $(\beta=-0.788, p<0.01)$ and the interaction between TMT longevity (squared) and dominant industry diversity $(\beta=0.388, p<0.1)$ were significant, explaining a significantly large part of the variance in $\operatorname{ROE}\left(R^{2}=0.53, p<0.01\right)$. For long-term $\mathrm{ROE}$, only the interaction between TMT longevity (squared) and age diversity $(\beta=0.729, p<0.05)$ was significant (see Model 2, Table IV), albeit explaining only a moderate part of the variance in firm performance $\left(R^{2}=0.29, p<0.01\right)$.

Graphical analyzes of the interaction effects. To further analyze the significant interaction effects found in step 4, a graphical procedure was applied (see Aiken and West, 1991, pp. 12-14, 69; Jaccard and Turrisi, 2003, p. 31). The effect of TMT diversity on ROE and ROE growth, respectively, was plotted for varying levels of the moderator, namely for minimum (TMT longevity is 0), low (one standard deviation below the mean), medium (mean), high (one standard deviation over the mean) and maximum (TMT longevity is 4) levels of TMT longevity. Figures 1-6 show the plots of the significant interactions between TMT diversity and TMT longevity on ROE (short term and long term) and ROE growth (short-term), respectively.

As can be seen in Figures 1-2, the effect of age diversity on ROE (long-term) and ROE growth (short-term) was moderated by TMT longevity. The form of the relationship was as expected in $H 1$. The effect of age diversity on ROE growth was positive up to a certain level of TMT longevity. In teams with high levels of TMT longevity, the relationship was negative. $H 1$ was thus confirmed.

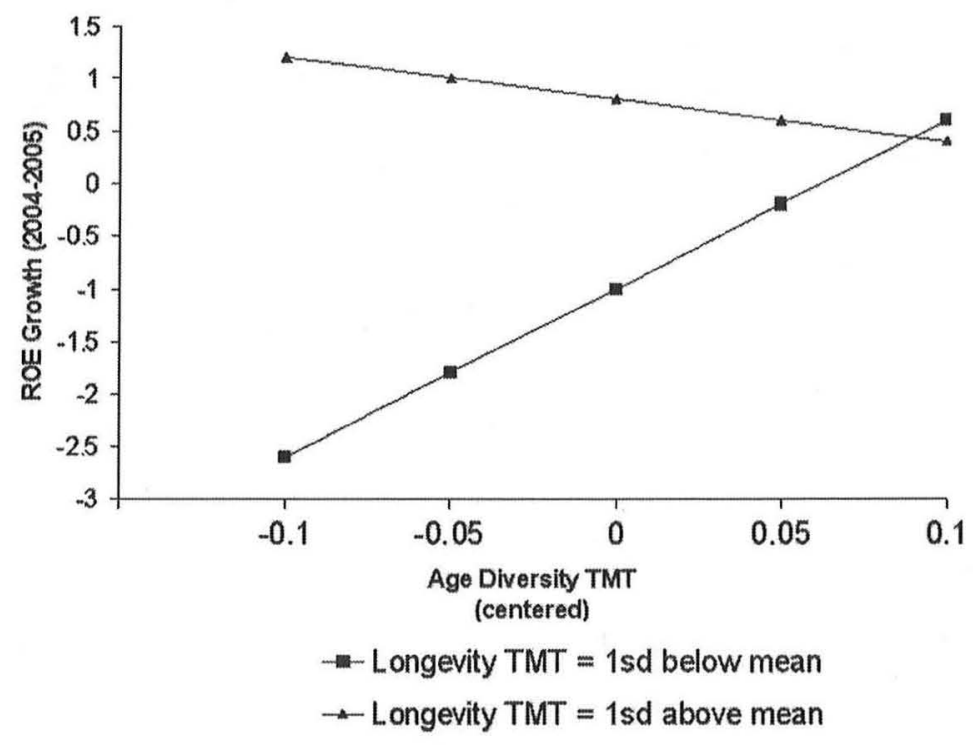

Figure 1. 


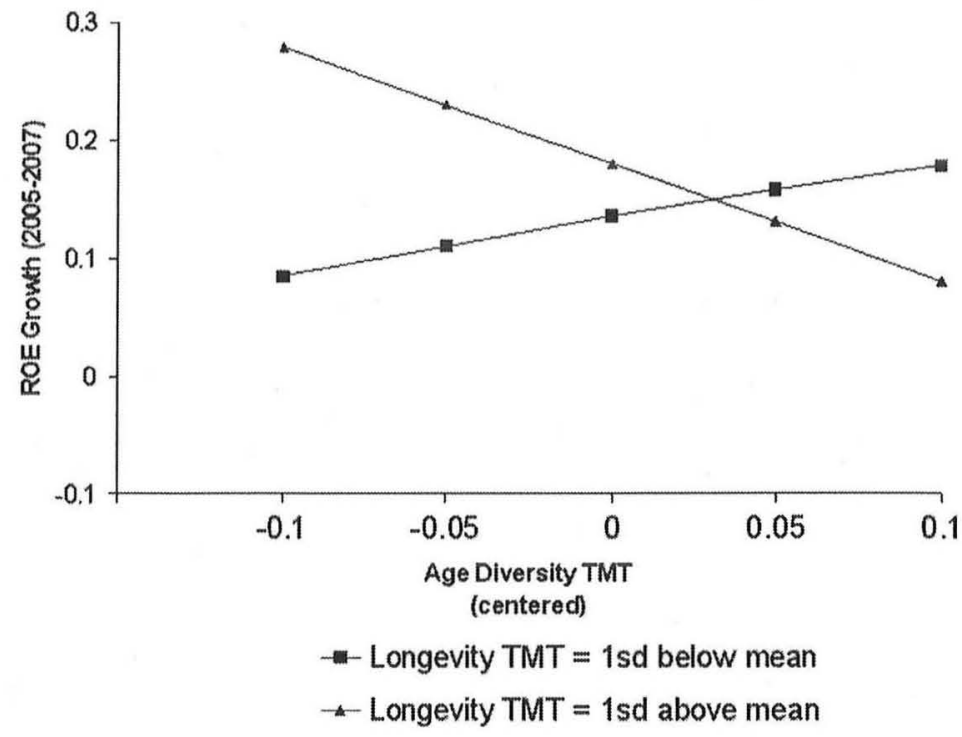

Figure 2 .

Age diversity and ROE growth (2005-2007)

Figure 3.

Tenure diversity and ROE growth (2004-2005)

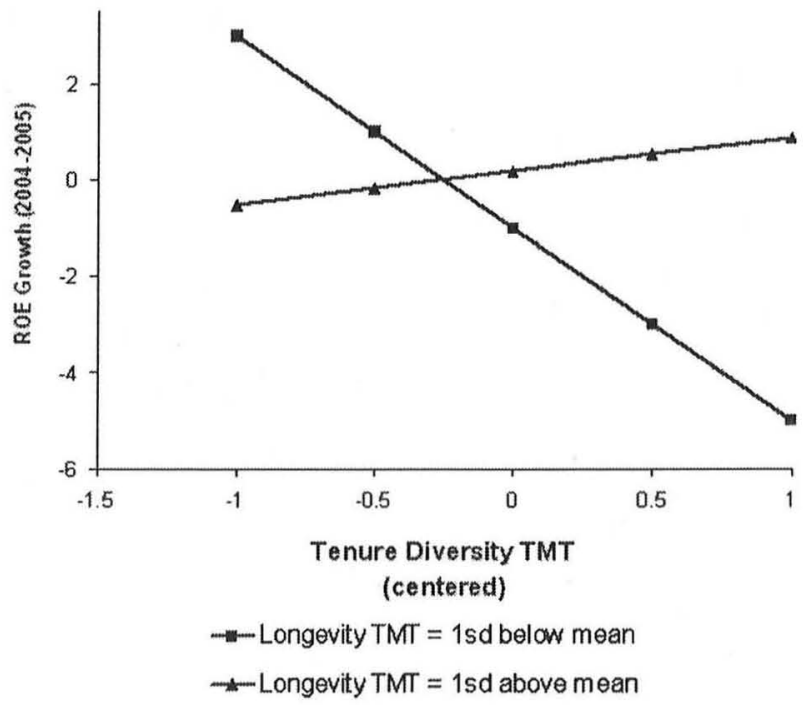

The effect of tenure diversity on short-term ROE growth and short-term ROE was moderated by TMT longevity. However, being u-shaped, the form of the relationship was contrary to $H 2$. The effect of tenure diversity on ROE growth and ROE was negative up to a certain level of TMT longevity (see Figures 3 and 4). For teams with low levels of TMT longevity, the relationship was positive. Hence, H2 was not confirmed.

The effect of educational diversity on short-term ROE growth was moderated by TMT longevity. Again, the form of the relationship was as expected in $H 3$. The effect 


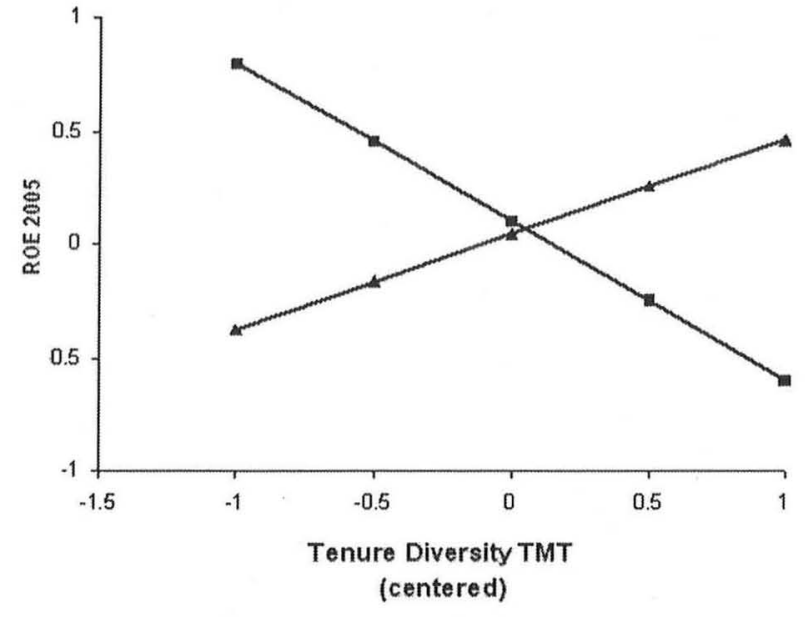

$\rightarrow-$ Longevity $T M T=1 \mathrm{sd}$ below mean

ॠ Longevity $\mathrm{TMT}=1 \mathrm{sd}$ above mean

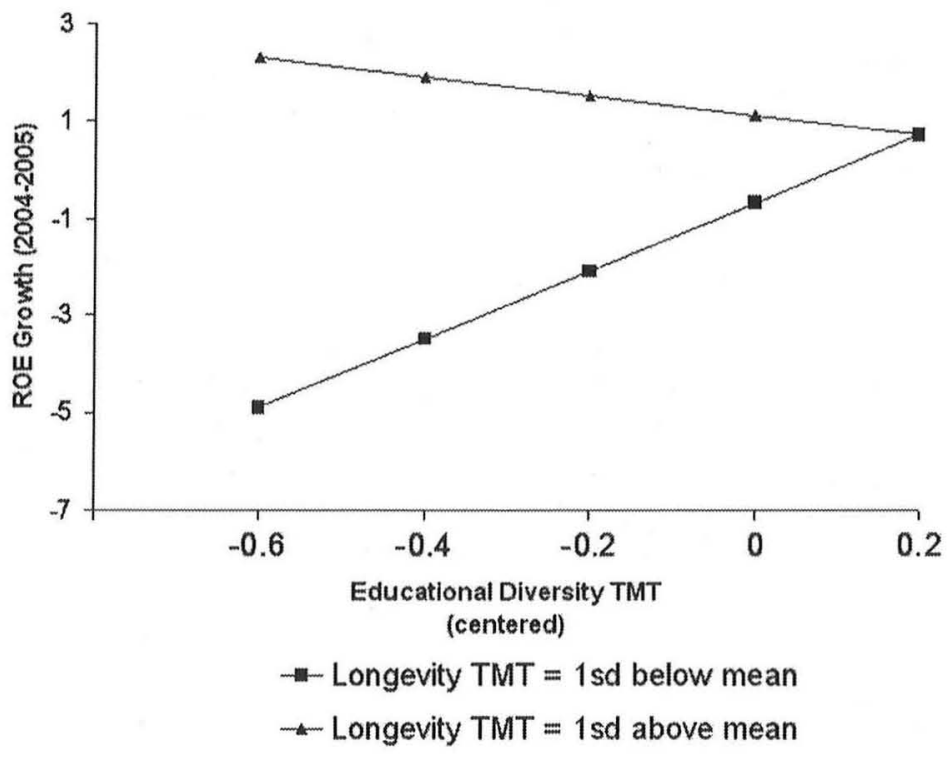

\section{5}

Figure 4. Tenure diversity and ROE

2005

of educational diversity on ROE growth was positive up to a certain level of TMT longevity (see Figure 5). For teams with high levels of TMT longevity the relationship was negative. The effect of dominant industry diversity on short-term ROE was moderated by TMT longevity. The effect of dominant industry diversity on ROE was positive up to a certain level of TMT longevity (see Figure 6). For teams with a high level of TMT longevity the relationship was negative, confirming $H 3$. 
346

Figure 6.

Dominant industry

diversity and ROE 2005

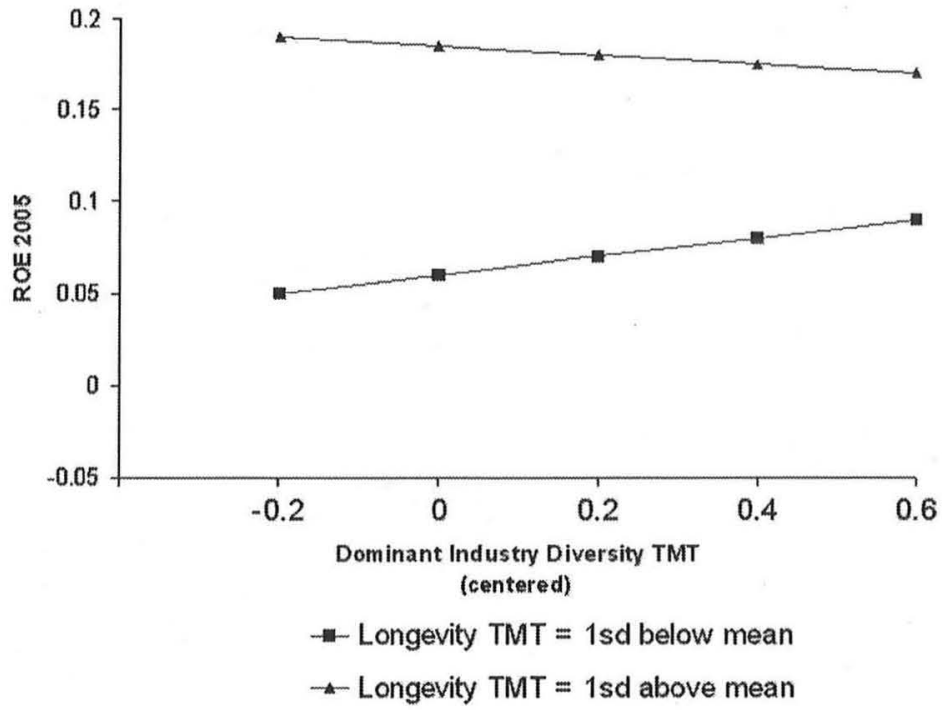

Discussion

Summary

Refining Carpenter's (2002) approach, TMT longevity was interpreted as a proxy for both beneficial and detrimental interaction processes in diverse TMTs. While medium levels of longevity facilitate social integration and collective learning, high levels of longevity may contribute to decreasing outside communication and a detrimental level of team cohesion. We thus expected a curvilinear moderating effect of TMT longevity on firm performance. The effect of diversity on firm performance will be positive in TMTs with short longevity; in TMTs with high longevity, this moderating effect will decline.

Analyzing a sample of 59 TMTs in German companies, this assumption was partly confirmed. However, the results differed according to different forms of diversity and different performance indicators. $H 1$, predicting a curvilinear moderating effect of longevity on the age diversity-performance relationship, was confirmed for short-term $\mathrm{ROE}$ growth and long-term ROE. $H 2$, predicting a curvilinear moderating effect of longevity on the tenure diversity-performance relationship, was not confirmed. Contrary to expectations, the curvilinear effect for short-term ROE and short-term ROE growth was u-shaped. The effect of tenure diversity on ROE growth and ROE was negative up to a certain level of TMT longevity; for teams with low levels of TMT longevity the relationship was positive. One explanation for this finding may be that the effects of tenure diversity may be particularly sensitive to the level of team tenure. The longer the team works together as a team, the lower the effects of tenure diversity. Tables I and II reveal a negative, albeit non-significant correlation between team tenure and tenure diversity.

$H 3$, predicting a curvilinear moderating effect of longevity on the dominant educational background diversity-performance relationship, was only confirmed for short-term ROE growth. H4, predicting a curvilinear moderating effect of longevity on the dominant industry experience, was only confirmed for short-term ROE. The results 
of our study thus challenge the idea of a linear positive moderating effect of longevity in TMTs (Carpenter, 2002). Whereas curvilinear effects of TMT diversity on TMT performance have been investigated several times (e.g., Richard et al., 2004), this is the first study to analyze curvilinear moderating effects in this context.

\section{Limitations and implications for future research}

The most obvious limitation of our study is the fact that the results were sensitive to the performance measures in use. In particular, none of the expected effects could be found for sales growth. However, previous studies on TMT diversity have reported similar effects with regard to different performance measures (e.g., Richard and Shelor, 2002).

Moreover, the results may be sensitive to the sector under study. Whereas ROE growth and sales growth are supposed to operate quite well even for a diverse sample (see Keck, 1997, p. 150), accounting measures such as ROE provide poor comparisons across sectors. However, due to the strong sectoral diversity of the sample under study, the kind of industry sector could not be controlled for (see Amburgey and Miner, 1992; Carpenter, 2002). Neither was it possible to adjust the performance variables for sector performance by subtracting the corresponding sector-average from each firm level measure (see Cannella et al., 2008, p. 773), because sufficient data to perform this step was not available. Accordingly, future studies on the curvilinear moderating effect of longevity in diverse TMTs should use samples with less variety in sectors i. Alternatively, they could try to collect the data necessary to adjust the performance variables for sector performance by subtracting the corresponding sector-average from each firm level measure (see Cannella et al., 2008, p. 773). Still another possibility would be to use advanced measures of economic performance, such as the economic value added concept (EVA; Stewart, 1990). However, those measures are quite complicated and require a series of adjustments when they are applied to different firms (see Brewer and Chandra, 1999; Weaver, 2001).

Further limitations arise from the selected sample of German companies. Due to missing data problems, the sample was rather small and therefore suffered from a lack of power when the complex hypotheses on the moderating effect of TMT longevity were tested. However, compared with other TMT studies, the sample size seems to be adequate. Moreover, by using this sample, the curvilinear effects of TMT longevity have been analyzed under relatively difficult conditions. The TMTs under study were not highly diverse on average (see Tables I and II). Hence, the results may become more consistent in TMTs with higher levels of diversity. Examining curvilinear moderation effects of longevity thus remains an interesting topic for further research. Apart from this, measuring TMT diversity requires the collection of detailed information on executive's backgrounds, and the sources for such data are not readily available for smaller companies (Cannella et al., 2008, p. 780). Hence, the sample was restricted to large firms. Our findings may thus not be generalizable to all firms in the examined sectors. Future research on the moderating effects of TMT longevity should therefore try to include TMTs from companies of different size.

\section{Practical implications}

Provided that the results of our study can be confirmed in future studies, the following practical implications can be formulated. First, TMT diversity is no guarantee for firm 
performance. Rather, TMT diversity can have both positive and negative effects on firm performance - practitioners should thus treat one-sided statements s suggesting overall positive effects of diversity with care.

Second, in order to fully use the potential of TMT diversity, organizations should distinguish between short-term effects and long-term effects of diversity. While TMT diversity can be beneficial in the short run, it can be detrimental in the long run, In long-tenured diverse TMTs, organizations should thus try to avoid the negative effects described above. According to the general literature on team diversity, team leaders are likely to play an important role in this context (Hüttermann and Boerner, in press). For example, by moderating team processes, team leaders should try to reduce the tendency for groupthink by facilitating external communication of team members. A similar effect of CEO's expertise and background characteristics on the functional diversity-performance relationship has recently been confirmed by Buyl et al. (2011). In addition, mentoring relationships between senior members of TMTs and diverse TMT members could be helpful (Carson et al., 2004).

\section{References}

Aiken, L.S. and West, S.G. (1991), Multiple Regression: Testing and Interpreting Interactions, Sage, Newbury Park, CA.

Allison, P.D. (1978), "Measures of inequality", American Sociological Review, Vol. 43, pp. 865-80.

Amburgey, T.L. and Miner, A.S. (1992), "Strategic momentum: the effects of repetitive, positional, and contextual momentum on merger activity", Strategic Management Journal, Vol. 13, pp. 335-48.

Bantel, K.A. and Jackson, S.E. (1989), "Top management and innovations in banking: does the composition of the top team make a difference?", Strategic Management Journal, Vol. 10, pp. 107-24.

Barrick, M.R., Bradley, B.H., Kristof-Brown, A.L. and Colbert, A.E. (2007), "The moderating role of top management team interdependence: implications for real teams and working groups", Academy of Management Journal, pp. 544-57.

Bassett-Jones, N. (2005), "The paradox of diversity management, creativity and innovation", Creativity \& Innovation Management, Vol. 14, pp. 169-75.

Blau, P.M. (1977), Inequality and Heterogeneity: A Primitive Theory of Social Structure, The Free Press, New York, NY.

Boone, C. and Hendriks, W. (2009), "Top management team diversity and firm performance: moderators of functional-background and locus-of control diversity", Management Science, Vol. 55, pp. 165-80.

Brewer, P.C. and Chandra, G. (1999), "Economic value added (EVA): its uses and limitations", SAM Advanced Management Journal, Vol. 64, pp. 4-11.

Bunderson, J.S. and Sutcliffe, K.M. (2002), "Comparing alternative conceptualizations of functional diversity in management teams: process and performance effects", Academy of Management Journal, Vol. 45, pp. 875-93.

Buyl, T., Boone, S., Hendriks, W. and Matthyssens, P. (2011), "Top management team functional diversity and firm performance: the moderating role of CEO characteristics", Journal of Management Studies, Vol. 48 No. 1, pp. 151-77.

Byrne, D. (1971), The Attraction Paradigm, Academic Press, New York, NY. 
Cannella, A.A. Jr, Park, J.H. and Lee, H.U. (2008), “Top management team functional background diversity and firm performance: examining the roles of team member colocation and environmental uncertainty", Academy of Management Journal, Vol. 51, pp. 768-84.

Carpenter, M.A. (2002), "The implications of strategy and social context for the relationship between top management team heterogeneity and firm performance", Strategic Management Journal, Vol. 23, pp. 275-84.

Carpenter, M.A. and Fredrickson, J.W. (2001), "Top management teams, global strategic posture, and the moderating role of uncertainty", Academy of Management Journal, Vol. 44, pp. 533-45.

Carpenter, M.A., Geletkanycz, M.A. and Sanders, W.G. (2004), "Upper echelons research revisited: antecedents, elements, and consequences of top management team composition", Journal of Management, Vol. 30, pp. 749-78.

Carson, C.M., Mosley, D.C. and Boyar, S.L. (2004), "Performance gains through diverse top management teams", Team Performance Management, Vol. 10 Nos 5/6, pp. 121-6.

Certo, S.T., Lester, R.H., Dalton, C.M. and andDalton, D.R. (2006), "Top management teams, strategy and financial performance: a meta-analytic examination", Journal of Management Studies, Vol. 43, pp. 813-39.

Chatterjee, S., Hadi, A.S. and Price, B. (2000), Regression Analysis by Example, Wiley, New York, NY.

Cohen, J. (2003), Applied Multiple Regression/Correlation Analysis for the Behavioral Sciences, Erlbaum, Mahwah, NJ.

Cohen, S.G. and Bailey, D.E. (1997), "What makes teams work: group effectiveness research from the shop floor to the executive suite", Journal of Management, Vol. 23, pp. 239-90.

Dougherty, D. (1992), "Interpretive barriers to successful product innovation in large firms", Organization Science, Vol. 3, pp. 179-202.

Eisenhardt, K.M. and Schoonhoven, C.B. (1990), "Organizational growth: linking founding team, strategy, environment, and growth among US semiconductor ventures, 1978-1988", Administrative Science Quarterly, Vol. 35, pp. 504-29.

Finkelstein, S. and Hambrick, D.C. (1996), Strategic Leadership, West, Minneapolis, MN.

Gebert, D., Boerner, S. and Kearney, E. (2006), "Cross-functionality and innovation in new product development teams: a dilemmatic structure and its consequences for the management of diversity", European Journal of Work \& Organizational Psychology, Vol. 15, pp. 431-58.

Hambrick, D.C. (1989), “Guest editor's introduction: putting top managers back into the strategy picture", Strategic Management Journal, Vol. 10, pp. 5-15.

Hambrick, D.C. (1994), "Top management groups: a conceptual integration and reconsideration of the team label", in Shaw, B.M. and Cummings, L. (Eds), Research in Organizational Behavior, JAI Press, Greenwich, CT, pp. 171-214.

Hambrick, D.C. (1995), "Fragmentation and the other problems CEOs have with their top management teams", California Management Review, Vol. 37, pp. 110-27.

Hambrick, D.C. (2007), "Upper echelons theory: an update", Academy of Management Review, Vol. 32, pp. 334-43.

Hambrick, D.C. and D'Aveni, R.A. (1992), “Top team deterioration as part of the downward spiral of large corporate bankruptcies”, Management Science, Vol. 38, pp. 1445-66. 
Hambrick, D.C. and Mason, P.A. (1984), "Upper echelons: the organization as a reflection of its top managers", The Academy of Management Review, Vol. 9, pp. 193-206.

Hambrick, D.C., Cho, T.S. and Chen, M.J. (1996), "The Influence of top management team heterogeneity on firms competitive moves", Administrative Science Quarterly, Vol. 41, pp. 659-84.

Hamilton, L.C. (2006), Statistics with Stata: Updated for Version 9, Thomson Brooks/Cole, Belmont, CA.

Harrison, D.A., Price, K.H. and andBell, M.P. (1998), "Beyond relational demography: time and the effects of surface- and deep-level diversity on work group cohesion", Academy of Management Journal, Vol. 41, pp. 96-107.

Hüttermann, H. and Boerner, S. (in press), "Fostering innovation in functionally diverse teams: the two faces of transformational leadership", European Journal of Work and Organizational Psychology.

Jaccard, J. and Turrisi, R. (2003), Interaction Effects in Multiple Regression, Sage, Thousand Oaks, CA.

Jackson, S.E., May, K.E. and Withney, K. (1995), "Under the dynamics of diversity in decision-making teams", in Guzzo, R.A. and Salas, E. (Eds), Team Effectiveness and Decision Making in Organizations, Jossey-Bass, San Francisco, CA, pp. 204-61.

Jackson, S.E., Brett, J.F., Sessa, V.L., Cooper, D.M., Julin, J.A. and Peyronnin, K. (1991), “Some differences make a difference: individual dissimilarity and group heterogeneity as correlates of recruitment, promotions and turnover", Journal of Applied Psychology, Vol. 76, pp. 675-89.

Janis, I.L. (1982), Groupthink: Psychological Studies of Policy Decisions and Fiascoes, Houghton Mifflin, Boston, MA.

Jehn, K.A., Northcraft, G.B. and Neale, M.A. (1999), "Why differences make a difference: a field study of diversity, conflict and performance in workgroups", Administrative Science Quarterly, Vol. 44, pp. 741-63.

Katz, R. (1982), "The effects of group longevity on project communication and performance", Administrative Science Quarterly, Vol. 27, pp. 81-104.

Keck, S.L. (1997), "Top management team structure: differential effects by environmental context", Organization Science, Vol. 8, pp. 143-56.

Kiefer, S. (2005), "Top management team diversity and firm performance: investigating german companies", unpublished Master thesis, University of Konstanz, Konstanz.

Kilduff, M., Angelmar, R. and Mehra, A. (2000), "Top management-team diversity and firm performance: examining the role of cognitions", Organization Science, Vol. 11, pp. 21-34.

Knight, D., Pearce, C., Smith, K.G., Olian, H., Smith, K.A. and Flood, P. (1999), “Top management team diversity, group process, and strategic consensus", Strategic Management Journal, Vol. 20, pp. 445-65.

Leblanc, R. and Schwartz, M.S. (2007), "The black box of board process: gaining access to a difficult subject", Corporate Governance: An International Review, Vol. 15, pp. 843-51.

Lovelace, K., Shapiro, D.L. and Weingart, L.R. (2001), "Maximizing cross-functional new product teams innovativeness and constraint adherence: a conflict communications perspective", The Academy of Management Journal, Vol. 44, pp. 779-93.

Michel, J.G. and Hambrick, D.C. (1992), "Diversification posture and top management team characteristics", The Academy of Management Journal, Vol. 35, pp. 9-37. 
Milliken, F.J. and Martins, L.L. (1996), "Searching for common threads: understanding the multiple effects of diversity in organizational groups", Academy of Management Review, Vol. 21, pp. 402-33.

Mohammed, S. and Angell, L.C. (2004), "Surface- and deep-level diversity in workgroups: Examining the moderating effects of team orientation and team process on relationship conflict", Journal of Organizational Behavior, Vol. 25, pp. 1015-39.

Murray, A.I. (1989), “Top management group heterogeneity and firm performance”, Strategic Management Journal, Vol. 10, pp. 125-41.

O'Reilly, C.A., Caldwell, D.F. and Barnett, W.P. (1989), “Work group demography, social integration, and turnover", Administrative Science Quarterly, Vol. 34, pp. 21-37.

Otley, D. (2007), "Accounting performance measurement: a review of its purposes and practices", in Neely, A.D. (Ed.), Business Performance Measurement: Unifying Theories and Integrating Practice, Cambridge University Press, Cambridge, pp. 11-35.

Pegels, C.C., Song, Y.I. and Yang, B. (2000a), "Management heterogeneity, competitive interaction groups, and firm performance", Strategic Management Journal, Vol. 21, pp. 911-23.

Pegels, C.C., Song, Y.I. and Yang, B. (2000b), "The impact of managerial characteristics on strategic assets management capabilities”, Team Performance Management, Vol. 12 Nos 7/8, pp. 97-106.

Pelled, L.H., Eisenhardt, K.M. and andXin, K.R. (1999), "Exploring the black box: an analysis of work group diversity, conflict, and performance", Administrative Science Quarterly, Vol. 44, pp. 1-28.

Qin, J. (2007), "Research contexts: a potential means of dissecting the diversity paradox", Proceedings of the 13th Asia Pacific Management Conference, Melbourne, Australia, pp. 252-60.

Rentsch, J.R. and Klimoski, R.J. (2001), "Why do great minds think alike? Antecedents of team member schema agreement”, Journal of Organizational Behavior, Vol. 22, pp. 107-20.

Richard, O.C. and Shelor, R.M. (2002), "Linking top management team age heterogeneity to firm performance: juxtaposing two mid-range theories", International Journal of Human Resource Management, Vol. 13, pp. 958-74.

Richard, O.C., Barnett, T., Dwyer, S. and Chadwick, K. (2004), "Cultural diversity in management, firm performance, and the moderating role of entrepreneurial orientation dimensions", Academy of Management Journal, Vol. 47, pp. 255-66.

Schippers, M.C., Den Hartog, D.N., Koopman, P.L. and Wienk, J.A. (2003), "Diversity and team outcomes: the moderating effects of outcome interdependence and group longevity and the mediating effect of reflexivity", Journal of Organizational Behavior, Vol. 24, pp. 779-802.

Seashore, S.E. (1977), Group Cohesiveness in the Industrial Work Group, Arno Press, New York, NY.

Sethi, R., Smith, D.C. and andPark, C.W. (2001), "Cross-functional product development teams, creativity, and the innovativeness of new consumer products", Journal of Marketing Research, Vol. 38, pp. 73-85.

Simons, T., Pelled, L.H. and Smith, K.A. (1999), "Making use of difference: diversity, debate, and decision comprehensiveness in top management teams", The Academy of Management Journal, Vol. 42, pp. 662-73.

Smith, K.G., Smith, K.A., Olian, J.D., Sims, H.P. Jr, O’Bannon, D.P. and Scully, J.A. (1994), “Top management team demography and process: the role of social integration and communication", Administrative Science Quarterly, Vol. 39, pp. 412-38. 
Stewart, G.B. (1990), The Quest for Value: The EVA TM Management Guide, Harper Business, New York, NY.

Tajfel, H. and Turner, J.C. (1986), "The social identity theory of intergroup behavior", in Worchel, S. and Austin, W.G. (Eds), Psychology of Intergroup Relations, Nelson-Hall, Chicago, IL, pp. 7-24.

Turner, J.C., Hogg, M.A., Oakes, P.J., Reicher, S.D. and Wetherell, M.S. (1987), Rediscovering the Social Group: A Self-categorizing Theory, Blackwell, Oxford.

Van der Vegt, G.S. and Bunderson, J.S. (2005), "Learning and performance: the importance of collective team identification", Academy of Management Journal, Vol. 48, pp. 532-47.

Van Knippenberg, D., De Dreu, C.K. and Homan, A.C. (2004), "Work group diversity and group performance: an integrative model and research agenda", Journal of Applied Psychology, Vol. 89, pp. 1008-22.

Vroom, V.H. and Pahl, B. (1971), "Relationship between age and risk taking among managers", Journal of Applied Psychology, Vol. 55, pp. 399-405.

Webber, S.S. and Donahue, L.M. (2001), "Impact of highly and less job-related diversity on work group cohesion and performance: a meta-analysis", Journal of Management, Vol. 27, pp. $141-62$.

Weaver, S.C. (2001), "Measuring economic value added: a survey of the practices of EVA proponents", Journal of Applied Finance, Vol. 11, pp. 50-60.

Wegner, D.M. (1995), "A computer network model of human transactive memory", Social Cognition, Vol. 13, pp. 319-39.

West, C.T. and Schwenk, C.R. (1996), "Top management team strategic consensus, demographic homogeneity and firm performance: a report of resounding non-findings", Strategic Management Journal, Vol. 17, pp. 571-6.

Wiersema, M.F. and Bantel, K.A. (1992), "Top management team demography and corporate strategic change", Academy of Management Journal, Vol. 35, pp. 91-121.

Wiersema, M.F. and Bantel, K.A. (1993), "Top management team turnover as an adaptation mechanism: the role of the environment", Strategic Management Journal, Vol. 14, pp. 485-504.

Williams, K. and O'Reilly, C.A. (1998), "Demography and diversity in organizations", Research in Organizational Behavior, Vol. 20, pp. 77-140.

Wirth, G., Arnold, M. and Greene, M. (2004), Corporate Law in Germany, Beck, München.

Zenger, T.R. and Lawrence, B.S. (1989), "Organizational demography: the differential effects of age and tenure distributions on technical communication", The Academy of Management Journal, Vol. 32, pp. 353-76.

\section{Further reading}

Finkelstein, S. and Hambrick, D.C. (1990), "Top-management-team tenure and organizational outcomes: the moderating role of managerial discretion", Administrative Science Quarterly, Vol. 35, pp. 484-503.

Samra-Fredericks, D. (2000), "Doing boards-in-action research: an ethnographic approach for the capture and analysis of directors and senior managers interactive routines", Corporate Governance: An International Review, Vol. 8, pp. 244-57. 


\begin{abstract}
About the authors
Sabine Boerner $(\mathrm{PhD})$ is a Professor of Management, esp. Strategy and Leadership, at the University of Konstanz. Her research interests include team research, strategy, and leadership. She has published several books and papers in international journals. Sabine Boerner is the corresponding author and can be contacted at: sabine.boerner@uni-konstanz.de

Marius Linkohr is a Research Fellow at the Chair of Management, esp. Strategy and Leadership, at the University of Konstanz.

Sabine Kiefer is a Research Fellow at the Chair of Management, esp. Strategy and Leadership, at the University of Konstanz.
\end{abstract}

